\title{
Formation of Novgorod as a Center of Radio-Electronic Industry in 1950-1960s
}

\author{
Makarova E.A. \\ Yaroslav-the-Wise Novgorod State University, \\ Veliky Novgorod, Russia, \\ Elena.Makarova@novsu.ru
}

\author{
Petrov M.N. \\ Yaroslav-the-Wise Novgorod State University, \\ Veliky Novgorod, Russia, \\ Mikhail.N.Petrov@novsu.ru
}

\begin{abstract}
The article examines the process of formation of radio-electronic industry in Novgorod in the post-war period which began with construction and development of capacities of several factories that produced defense products and consumer goods, especially telecommunication ones. In 1950-60s, conditions in the whole country caused the necessity of accelerated development of the newest fields of science, technology and production. The key point is the reform of individual enterprises into the research and production associations such as Volna, Kvant, Planeta, Kompleks, Elkon, Start, Transvit that have a wide range of products, their effective functioning has required the modernization of the training system for specialists in technical fields. The authors analyze certain aspects of formation of polytechnic education of secondary vocational and higher levels in the conditions of a shortage of engineering and technical personnel, starting with the opening of branches of large Leningrad technical higher educational institutions in the town which were subsequently transformed into independent Novgorod Polytechnic Institute and Novgorod Technical School of the Radio-Electronic Industry. The social consequences of transforming the region into the center of the radio-electronic industry such as providing the population with qualified and well paid jobs, constructing new micro-districts at the expense of enterprises, and solving the housing problem are also studied. The conclusion has been made that the Novgorod radio-electronic industry occupied a prominent place in the economy of the Soviet Union by the beginning of 1970s.
\end{abstract}

Keywords-radio electronics, scientific production association, electronic industry, polytechnic education

\section{INTRODUCTION}

The problem of determining the development strategy of Novgorod region existed even at the moment of the region formation on July 5, 1944. The status of a pre-war townmuseum of a district level with little industry and a small population did not correspond to the regional center. A stimulus for the regional growth was to be given by an industrial leap which turned to be effective, due to a favorable geographical position between Moscow and Leningrad, sufficient railway, road and water communications, the predominant number of rural residents as a personnel reserve.
During the indicated research period the region formed a fundamental productive base for domestic rapidly developing advanced and scientifically intensive fields of the radioelectronic industry.

Researchers examining the mechanisms of industrial potential growth traditionally point to the need to simultaneously create a system for training specialists capable of providing this process. Thus, V.A. Fedorov, N.V. Tretyakova, A.V. Kobzev consider the training of scientific and industrial personnel at every historical modernization period as a very important problem which must be solved in accordance with primary strategic tasks $[1 ; 2]$. According to L.I. Shagrina and G.S. Shagrina, the training for innovative and active specialists in higher education requires instilling in them the ability to improve and develop their intellectual and general cultural level, generate new ideas in their professional fields [3]. In the conditions of the lack of our own regional experience of polytechnic education, the way out was found when the branches of leading Leningrad Electro-technical Institute and Leningrad Radio-technical School were opened, their functioning laid the high quality base for subsequent development of regional independent Novgorod School of Electronic Industry (1966) and Novgorod Polytechnic Institute (1973).

\section{FINDINGS}

The Volna research and production association became the founder of the future Novgorod radio-electronics. The construction of the plant started in the northern part of Novgorod in the spring of 1948. At the same time, several groups of young people left for Leningrad, where they mastered professions of assemblers and regulators of radio equipment at the plant named after Kozitsky, one of the oldest enterprises of communication and telecommunications in Russia.

The industrial three-storey building was situated in Leningradskaya street; the quarter between the rampart, the border of the old town, and the enterprise was built up with two-storey houses with apartments for workers. The residential micro-district was informally called Shabrovka 
after the name of the construction initiator, plant director V.G. Shabrov.

In February, 1952, the radio plant, which Novgorod residents informally called "mailbox 11 ", released the first batch of measuring instruments. (In those years a mailbox name meant classified production which fulfilled the orders from the Defense Ministry and had military acceptance.) At the plant power suppliers for radio stations were mastered, since 1956 the first domestic studio cameras were produced. The first Soviet nuclear power stations and the first nuclear Lenin icebreaker were equipped with industrial television installations.

In January 1958, the construction of "mailbox 15", or a television plant, was begun not far from the radio plant. Only seven months later, the first hundred of black and white KVN49 television sets were produced. The first available device which allowed receiving three, then existing, television programs had a $18 \mathrm{~cm}$ kinescope which required a magnifying lens. Two years later, the plant switched to mass production of a modern model - the Volkhov TV set. Both at the first facility of the radio-electronic industry and the second one, military products took the leading place.

In the same 1958, the buildings of a "mailbox 21 ", or a plant of semiconductor triodes (later - devices) began to be erected on the banks of the Volkhov in the center of Torgovaya Side. In August 1959, the first 1100 transistors were released, that number having been timed to coincide with the anniversary of Novgorod. Conveyer mechanical lines for preparing crystals and assembling germanium transistors were developed and implemented. Collaborators of the plant's Special Design Bureau developed and implemented the production of transistors with a special characteristic for the automated amplification of television channels.

It is obvious that the first Novgorod plants of the electronic industry focused on a television field which was then new. This was confirmed officially by the decision of Leningrad Soviet for people's economy "On development of radioengineering production in the town of Novgorod". A new center for television and special technical equipment was made. Plants which were being designed and constructed were supposed to produce items and components: transformers, capacitors, relays, microcircuits, kinescopes. The furniture factory was also engaged to produce television cases.

At the enterprises a staff problem was urgent. Engineering positions in accordance with the state distribution were occupied by graduates of technical universities, mostly from Leningrad. But the demand was higher than the number of arrived specialists, besides it was necessary to solve many associated problems, such as housing and household ones. The solution was naturally found in preparing qualified engineering personnel in Novgorod itself.

At the beginning of 1961, the meeting of the enterprises' directors with the participation of Professor N.P. Bogorodsky, Rector of Leningrad Electro-Technical Institute named after V.I. Ulyanov-Lenin (LETI), was held. They made a decision to petition the regional authorities and the Ministry of Higher and Secondary Special Education (Minvuz) to open an evening general technical faculty of LETI in Novgorod. The former building of provincial Noble Assembly, in which Soviet institutions were then placed, situated on the Pobedy square in the town center, was used for classes. After the Great Patriotic War the building was reconstructed and used for Soviet Party School classes where district managers were trained. The former school had a four-storey hostel in the town center [4].

In October 1961, the faculty was opened. 170 persons (six student groups) which had passed successfully entrance exams began to study. Yu.S. Karpov, Candidate of Techical Sciences, was elected dean. Two accelerated education groups admitted immediately to the $4^{\text {th }}$ year were recruited from the plant workers with non-profile higher education, mainly they were graduates of Physical and Mathematical Faculty of the Novgorod State Pedagogical Institute.

Khrushchev's campaign for integrating school and life often made universities report on their successful implementation of "industrial training", although not every plant could correspond to a university [5]. But as for Novgorod students, they could have an industrial practice in the full extent at newly opened specialized plants. In addition, it was necessary to improve the mechanism of training teachers for the system of polytechnic higher and secondary special education, as well as of masters guiding the process of industrial education. In pedagogical universities new faculties were opened throughout the country, and by 1962 the system of training teachers of general technical disciplines included 123 universities [6].

In 1964, the evening general technical faculty of LETI was transformed into the Novgorod branch of LETI with daytime, evening and extramural courses in the following specialties: Semiconductor Devices, Design and Production of Radio Equipment and Radio Engineering. A.M. Kiselev, previously director of Novgorod plant of semiconductor devices, was appointed director of the branch. In the branch, sections of three departments of LETI were organized. In December of that year, the first graduation of engineers took place in the Semiconductor Devices specialty, and in June of the next year the graduation of engineers of the Design and Production of Radio Equipment specialty took place [7].

The branch was popular among graduates of Novgorod schools. In 1966, there were already 200 full-time students, and 250 part-time and evening students. Heads of the enterprises provided an effective assistance in the construction of new educational buildings and modern equipment of laboratories. In 1970, the Volna association and its director P.M. Iudin contributed to the erection of the first such building on the Stroiteley square.

In the same year, the increased scientific and methodological level of teachers and the material base achieved allowed contracting and performing the first research work. Afterwards, the research work (NIR) commissioned by the enterprises became the strong point of their activities with the wide involvement of students. In 1973, the Novgorod Polytechnic Institute was established on the basis of the branch.

The production demanded specialists of middle level in the same extent, since in the radio electronic production the number of different specialties including working ones that required knowledge at the level of the technical school grew steadily. Similarly with the establishment of the LETI branch in August, 1960, the Leningrad Soviet for people's economy 
decided to establish the Novgorod branch of Leningrad Radio Engineering School with evening and extramural departments in radio engineering specialties according to extramural and evening curricula. There was a shortage of full-time teachers as well as of technical equipment. In the initial period, in order to conduct training sessions, rooms were rented in other educational institutions; then, the branch was allocated the building of the regional printing house where redevelopment and major repair were made to meet the requirements of the educational process.

In 1964 the first graduation of technologists took place, in 1966 the branch was transformed into the Novgorod Technical School of Electronic Industry (NTEP) and students were recruited to the full-time department. The equipment of laboratories and classrooms, as well as the library fund acquisition were begun. In 1968, in a specially erected building of the NTEP in Leningradskaya street, more than thirty laboratories, numerous radio engineering and mechanical workshops were opened. Many years later, the Polytechnic College of NovSU became the successor of the Technical School.

In 1959, by the decree of the Central Committee of the CPSU and the Council of Ministers of the USSR "On improving the management of vocational and technical education in the USSR" dated July 11, 1959, No. 844 [8], the State Committee of the Council of Ministers of the USSR on vocational education was established instead of the Main Department of Labor Reserves. During 1959-1965 in the whole country the re-making of the system of state labor resources took place, and vocational technical schools of a single type were created in the form of urban and rural vocational technical schools (PTU) on the basis of 8 years school education [9].

Urban vocational technical schools trained workers, mainly metalworkers, for mechanical and auxiliary workshops. From 1954, the GPTU-5 (State Vocational Technical School) located in the abbot building of Yuryev monastery existed at the "mail box 11". Classrooms, a canteen and a small hostel were equipped. The park named in the honor of 1100 anniversary of Novgorod founded on Myachinskoe lake by the PTU students, as well as the former Trudovye Rezervy stadium remind us of that time.

Such a method of training workers as the industrial education for 10th graders was used for several years. Once a week, at plants, adolescents mastered the basics of such professions as a turner, a locksmith, a winder, and a picker. But as high school graduates were focused on entering universities, the experiment was stopped in 1966 due to its inefficiency.

Apprenticeship at plant became a more effective way of training workers. An apprentice mastered the basics of the specialty in the workplace with the help of experienced masters, studied theory in courses, took a qualification exam [10].

\section{CONCLUSION}

In 1960s, the atmosphere dictated the need for the accelerated development of the newest fields of science, technology and production. To guide and coordinate the process, in 1961 the State Committee of the Council of
Ministers of the USSR on electronic equipment was created, and in 1965 the Ministry of the electronic industry of the USSR was created [10]. A powerful impetus in the development of the Soviet economy in general and radio electronics in particular was brought by the September 1965 Plenum of the Central Committee of the CPSU, at which the issue of improving industrial management was discussed [11]. Economic independence of enterprises expanded, the transfer to the complex multi-variant planning based on a return to the sector management principle took place [12]

Sovnarkhozes (councils of people's economy) created in 1957 no longer met the requirements of complex management of all segments of industry and lost the integrity of scientific and industrial development [13]. The main indicator was the volume of products sold; inter-economic relationships were based on the principle of cost accounting. From the profits funds were formed for production development, social and cultural events, housing construction, stimulation with the introduction of the so-called $13^{\text {th }}$ salary which was premium paid taking into account the year results. In 1965, at enterprises, within the Kosygin economic reform, four new funds with more distinct conditions of expenses replaced the director's funds of Khrushchev period [14].

Despite the fact that a number of processes of the Soviet state building were of stagnant nature, the 70s years of the last century were the most successful for the electronics industry. Ultimately, from 1960 to 1990, the Soviet Union took the third place in the world in the field of the production of electronic components (and for certain types it was the second place, and even the first one) [15]. The development of the Novgorod radio electronic industry which continued to increase its productive capacities played a significant role in the process. Certain plants were reformed into the scientific and industrial associations such as Volna, Kvant, Planeta, Kompleks, Elkon, Start, Transvit, with a wide range of defense products and consumer goods. The successful economy beneficially influenced the social sphere. Tens of thousands of Novgorod citizens were provided with qualified and highly paid jobs. The town rapidly grew as the enterprises constructed new micro districts, thereby solving the housing problem. Branches of the associations that were established in the regional centers contributed to the development of the region. By the beginning of the $1970 \mathrm{~s}$, the Novgorod radio electronic industry took a prominent place in one of the leading sectors of the national economy of the Soviet Union.

\section{REFERENCES}

[1] V.A. Fedorov and N.V. Tretyakova, "Professional pedagogical education in Russia: historical and logical periodization" ["Professional'no-pedagogicheskoye obrazovaniye v Rossii: istorikologicheskaya periodizatsiya"], Education and Science [Obrazovaniye i nauka], 2017, vol. 3. pp. 93-119. (In Russ.). DOI: https://doi.org/10.17853/1994-5639-2017-3-93-119

[2] A.V. Kobzev, "University as a training center for knowledge-intensive business" ["Universitet kak tsentr podgotovki kadrov dlya naukoemkogo biznesa"], Education Studies [Voprosy obrazovaniya], 2007, vol. 2, pp. 161-170. (In Russ.).

[3] L.I. Sharygina and G.S. Sharygin, "New Russian Educational Program for Engineer Training in the Field of Radar and Remote Sensing", in Proceedings of IGARSS 2012. Preliminary Symposium, 2012, pp. 73617364. 
[4] "Veliky Novgorod is the cradle of Russian education" ["Veliky Novgorod - kolybel' rossiyskogo obrazovaniya"l, Veliky Novgorod, NovSU [Veliky Novgorod, NovGU], 2000, pp. 144-146. (In Russ.).

[5] A.A. Ilin, "Past, Present and Future of the Soviet University: Jubilee Histories of Higher Education Institutions in the 1930s - 1980s", Science Journal of Volgograd State University, History, Area Studies, International Relations [Vestnik Volgogradskogo gosudarstvennogo universiteta, Seriya 4, Istoriya, Regionovedenie, Mezhdunarodnye otnosheniya], 2020, vol. 25(2), pp. 93-102. (In Russ.). DOI: https://doi.org/10.15688/jvolsu4.2020.2.7

[6] V.A. Fedorov and N.V. Tretyakova, "The Development of Vocational Pedagogical Education in Russia (Organizational and Pedagogical Aspect)", International Journal of Environmental and Science Education, 2016, vol. 11(17), pp. 9803-9818. (In Russ.).

[7] B.I. Seleznev, "Institute of Electronic and Information Systems. History, infrastructure, innovation" ["Institut elektronnykh i informatsionnykh sistem. Istoriya, infrastruktura, innovatsii"], Veliky Novgorod, NovSU [Veliky Novgorod, NovGU], 2015, pp. 4-8. (In Russ.).

[8] Resolution of the Central Committee of the CPSU, the USSR Council of Ministers of July 11, 1959 N 844 "On improving the leadership of vocational education in the USSR" [Postanovleniye TSK KPSS, Sovmina SSSR ot 11.07.1959 N 844 "Ob uluchshenii rukovodstva professional'no-tekhnicheskim obrazovaniyem v SSSR"]. (In Russ.). Retrieved

from http://www.consultant.ru/cons/cgi/online.cgi?req=doc\&base=ESU\&n=4 1513

[9] E.M. Dorozhkin and I.A. Chernoskutova, "Problems of the formation of the domestic system of personnel training for vocational educational institutions: historical and genetic analysis" ["Problemy stanovleniya otechestvennoy sistemy podgotovki kadrov dlya professional'notekhnicheskikh uchebnykh zavedeniy: istoriko-geneticheskiy analiz"] Education and Science [Obrazovaniye i nauka], 2020, vol. 22(3). pp. 172-204. (In Russ.). DOI: https://doi.org/10.17853/1994-5639-20203-172-204
[10] V.M. Proleiko, "Essays on the history of Russian electronics" in: B.M. Malashevich (Ed.), [Ocherki istorii rossiyskoy elektroniki], Moscow: Tekhnosfera, 2011. (In Russ.).

[11] Resolution of the Central Committee of the CPSU, the USSR Council of Ministers of 10/04/1965 N 729 (ed.of 12/08/1987) "On improving planning and strengthening economic incentives for industrial production" [Postanovleniye TSK KPSS, Sovmina SSSR ot 04.10.1965 N 729 (red.ot 08.12.1987) "O sovershenstvovanii planirovaniya i usilenii ekonomicheskogo stimulirovaniya promyshlennogo proizvodstva"]. (In Russ.). Retrieved from http://www.consultant.ru/cons/cgi/online.cgi?req=doc\&base=ESU\&n=8 83\#07140350089300715

[12] R.M. Nureev, "Command economy in the industrial era (on the example of the USSR)" ["Komandnaya ekonomika v industrial'nuyu epokhu (na primere SSSR)"], Terra Economicus, 2012, vol. 10(4), pp. 115-138. (In Russ.).

[13] S.I. Podolsky and A.Yu. Davydov, "The system of economic councils is undoubtedly progressive: from the history of the Leningrad Council of National Economy (1957-1966)" ["Sistema sovnarkhozov yavlyaetsya bezuslovno progressivnoy: iz istorii leningradskogo Soveta Narodnogo Khozyaystva (1957-1966 gody)"], New Historical Bulletin [Novyy istoricheskiy vestnik], 2016, vol. 4(50), pp. 80-89. (In Russ.).

[14] A.V. Smetanin, "Directors' funds of Soviet enterprises (1946-1965): a resource for transforming the social order" ["Direktorskiye fondy sovetskikh predpriyatiy (1946-1965 gg.): resurs transformatsii sotsial'nogo poryadka"], Bulletin of Perm University. History [Vestnik Permskogo universiteta. Istoriya], 2018, vol. 2(41), pp. 145-154. (In Russ.). DOI: https://doi.org/10.17072/2219-3111-2018-2-145-154

[15] A.A. Shokin, "The electronic industry of the USSR in the 60-80s of the twentieth century" ["Elektronnaya promyshlennost' SSSR v 60-80-e gody XX veka"], REDS: Telecommunication devices and systems [REDS: Telekommunikatsionnyye ustroystva i sistemy], 2014, vol. 4. pp. 443-447. (In Russ.). 